University of Nebraska - Lincoln

DigitalCommons@University of Nebraska - Lincoln

\title{
Retrieval of canopy height using moderate-resolution imaging spectroradiometer (MODIS) data
}

\author{
Zhuosen Wang \\ Beijing Normal University, wangzhs@bu.edu \\ Crystal B. Schaaf \\ Boston University \\ Philip Lewis \\ University College London \\ Yuri Knyazikhin \\ Boston University \\ Mitchell A. Schull \\ Boston University \\ See next page for additional authors
}

Follow this and additional works at: https://digitalcommons.unl.edu/nasapub

Part of the Physical Sciences and Mathematics Commons

Wang, Zhuosen; Schaaf, Crystal B.; Lewis, Philip; Knyazikhin, Yuri; Schull, Mitchell A.; Strahler, Alan H.; Yao, Tian; Myneni, Ranga B.; Chopping, Mark J.; and Blair, Bryan J., "Retrieval of canopy height using moderateresolution imaging spectroradiometer (MODIS) data" (2011). NASA Publications. 95.

https://digitalcommons.unl.edu/nasapub/95

This Article is brought to you for free and open access by the National Aeronautics and Space Administration at DigitalCommons@University of Nebraska - Lincoln. It has been accepted for inclusion in NASA Publications by an authorized administrator of DigitalCommons@University of Nebraska - Lincoln. 


\section{Authors}

Zhuosen Wang, Crystal B. Schaaf, Philip Lewis, Yuri Knyazikhin, Mitchell A. Schull, Alan H. Strahler, Tian Yao, Ranga B. Myneni, Mark J. Chopping, and Bryan J. Blair 


\title{
Retrieval of canopy height using moderate-resolution imaging spectroradiometer (MODIS) data
}

\author{
Zhuosen Wang a,b,*, Crystal B. Schaaf ${ }^{\mathrm{b}}$, Philip Lewis ${ }^{\mathrm{c}}$, Yuri Knyazikhin ${ }^{\mathrm{b}}$, Mitchell A. Schull ${ }^{\mathrm{b}}$, \\ Alan H. Strahler ${ }^{\mathrm{b}}$, Tian Yao ${ }^{\mathrm{a}, \mathrm{b}}$, Ranga B. Myneni ${ }^{\mathrm{b}}$, Mark J. Chopping ${ }^{\mathrm{d}}$, Bryan J. Blair ${ }^{\mathrm{e}}$

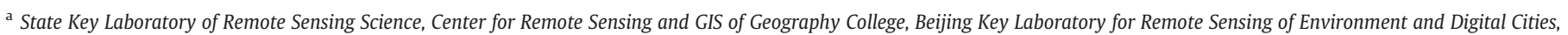 \\ Beijing Normal University, Beijing, China \\ ${ }^{\mathrm{b}}$ Center for Remote Sensing, Department of Geography and Environment, Boston University, Boston, MA, USA \\ c Department of Geography and National Centre for Earth Observation (NCEO), University College London, UK \\ d Department of Earth and Environmental Studies, Montclair State University, Montclair, NJ, USA \\ e Laser Remote Sensing Laboratory, NASA Goddard Space Flight Center, Greenbelt, MD, USA
}

\section{A R T I C L E I N F O}

\section{Article history:}

Received 5 October 2010

Received in revised form 10 February 2011

Accepted 13 February 2011

Available online 12 March 2011

\section{Keywords:}

Canopy height

Forest structure

Biomass

New England forests

La Selva Forest

LVIS

MODIS BRDF/Albedo product

\begin{abstract}
A B S T R A C T
In this study we use the $500 \mathrm{~m}$ Moderate Resolution Imaging Spectroradiometer (MODIS) Bidirectional Reflectance Distribution Function (BRDF) product to develop multivariate linear regression models that estimate canopy heights over study sites at Howland Forest, Maine, Harvard Forest, Massachusetts and La Selva Forest, Costa Rica using (1) directional escape probabilities that are spectrally independent and (2) the directional spectral reflectances used to derive the directional escape probabilities. These measures of canopy architecture are compared with canopy height information retrieved from the airborne Laser Vegetation Imaging Sensor (LVIS). Both the escape probability and the directional reflectance approaches achieve good results, with correlation coefficients in the range $0.54-0.82$, although escape probability results are usually slightly better. This suggests that MODIS $500 \mathrm{~m}$ BRDF data can be used to extrapolate canopy heights observed by widely-spaced satellite LIDAR swaths to larger areas, thus providing wide-area coverage of canopy height.
\end{abstract}

(C) 2011 Elsevier Inc. All rights reserved.

\section{Introduction}

Forest structure is an important factor in the estimation of energy and carbon fluxes between land and atmosphere and is required by modelers at regional and global scales. Of primary importance is above-ground standing biomass, which is estimated in the field from basal area and canopy height using empirically-derived allometric functions (Jenkins et al., 2004; Tritton \& Hornbeck, 1982). Height metrics alone have been used successfully as a surrogate for basal area or diameter-breast-height (DBH) and have a well defined relationship with above-ground carbon storage (Patenaude et al., 2004).

A relatively high correlation between the H100 canopy height estimates from NASA's active Laser Vegetation Imaging Sensor (LVIS) and field measured maximum canopy height values has already been documented for the Howland Forest (Anderson et al., 2006; Kimes et al., 2006). However, a major limitation of airborne LIDAR sensors such as LVIS is that only a narrow swath is imaged on each overpass (e.g. $2-\mathrm{km}$ swaths of LIDAR are obtained from an altitude of $10 \mathrm{~km}$ ) as compared to the wide swaths of orbital, passive optical sensors. Therefore efficient

\footnotetext{
* Corresponding author at: Center for Remote Sensing, Department of Geography and Environment, Boston University, Boston, MA, USA. Tel.: +1 6173532088.

E-mail address: wangzhs@bu.edu (Z. Wang).
}

methods to estimate forest canopy height using optical remote sensing are now being developed. Although there is no direct physical relationship between canopy height and reflectance, reflectance are affected by leaf area index, canopy fraction and 3D canopy structure, all of which may be locally related to canopy height and variability. Chopping et al. (2008) used a Simple Geometric Model (SGM), a hybrid geometric-optical model, in the southwestern US to estimate canopy height based on Multiangle Imaging Spectrometer (MISR) data and also applied this method with MODIS data (Chopping et al., in press). Heiskanen (2006) documented the ability of the MISR Bidirectional Reflectance Factors (BRF) (Martonchik et al., 1998) to estimate tree cover and height in the Fennoscandinavia tundra-taiga transition zone. Similarly, Kimes et al. (2006) retrieved the canopy height of the mixedconifer forest at the Howland Experimental Forest, Maine, from high resolution airborne AirMISR data using a correlation approach calibrated by heights retrieved from LVIS. However, recent results have also shown that canopy spectral absorption and scattering, and thus canopy structure information, can be described well by spectrally invariant variables derived from multi-angle satellite observations (Huang et al., 2007, Knyazikhin et al., 1998, 2011; Lewis \& Disney, 2007; Mõttus, 2007; Mõttus \& Stenberg, 2008; Mõttus et al., 2007; Rautiainen \& Stenberg, 2005; Schull et al., 2007; Smolander \& Stenberg, 2005; Stenberg, 2007). Therefore Schull et al. (2007) used spectrally invariant variables derived 
from AirMISR data to achieve higher correlations with LVIS heights at a spatial resolution of $283 \mathrm{~m}$, suggesting that multispectral, multiangle, moderate resolution space-based imaging such as from MISR or MODIS, when used with spectrally invariant variables, may also be useful in providing canopy vertical structure information over large areas.

The purpose of this study is to quantify the accuracy of forest canopy heights retrieved from the MODIS BRDF product at a $500 \mathrm{~m}$ gridded resolution using a spectral invariants approach over the Howland Experimental Forest, Maine, the Harvard Forest, Massachusetts, and La Selva Forest, Costa Rica. Two linear models are developed; one from the spectrally invariant parameters and one from the reflectance directly. This work demonstrates that multispectral, multi-angular observations from MODIS have the potential to be used synergistically with airborne and, eventually, spaceborne LIDAR data to expand the retrieval of forest canopy height and structure information.

\section{Data used}

\subsection{Study area}

The Howland Experimental Forest (45.2 N, 68.74 W), a U.S. Forest Service research site, is an evergreen needleleaf forest located in central Maine, U.S.A. (Fig. 1). The dominant species at the Howland Forest are red spruce, hemlock, and white pine. The Harvard Forest $(42.54 \mathrm{~N}, 72.17 \mathrm{~W})$, a mixed deciduous broadleaf and evergreen needleleaf forest, lies in central Massachusetts, U.S.A. The dominant species are red maple, red oak, birch, and hemlock. La Selva is a tropical rain forest $(10.36 \mathrm{~N}, 80.04 \mathrm{~W})$ located at the confluence of two major rivers in the Caribbean lowlands of northern Costa Rica.

\subsection{LVIS data}

LVIS (Blair et al., 1999) is an airborne, full waveform-recording LIDAR sensor developed and operated by the Laser Remote Sensing Laboratory, NASA Goddard Space Flight Center. The footprint of LVIS observation is nominally spaced at $20 \mathrm{~m}$ diameter. The LVIS data used in our analysis were acquired at the Howland and Harvard forests during a NASA Terrestrial Ecology Program aircraft campaign in the summer of 2003 and are publicly available at (WWW1). The spatial coverage of LVIS data is about $61 \times 9 \mathrm{~km}$ at Howland Forest and $35 \times 12 \mathrm{~km}$ at Harvard Forest (Fig. 1). The LVIS data for La Selva Forest were acquired in late March,
2005 and cover about $30 \times 22 \mathrm{~km}$ (WWW1). The LVIS H100 canopy height, which is the difference between the elevation of the highest detectable return and the ground elevation (Blair et al., 1999; Kimes et al., 2006), is used in this study. For each site, we generated a 500-m grid of LVIS canopy heights matching the spatial resolution of the MODIS BRDF product using the mean $\mathrm{H} 100$ value within the grid window. Table 1 lists the LVIS-derived information from the three forests at a $500 \mathrm{~m}$ spatial resolution.

\subsection{MODIS data}

The MODIS BRDF/Albedo Product (MOD43A) (Lucht et al., 2000; Schaaf et al., 2002) is a MODIS standard product that provides the weighting parameters associated with the RossThick-LiSparse Reciprocal (RTLSR) BRDF model that best describes the reflectance anisotropy of each pixel at a 500-m gridded resolution.

MODIS atmospherically-corrected, cloud-free, directional data from August, 2003 were used to retrieve the RTLSR BRDF model to obtain high-quality, pixel-by-pixel full inversions for the Howland and Harvard forests. Due to persistent cloud cover, a slightly longer period (from late Feb to early April) was used in order to obtain sufficient full-inversions for La Selva Forest during 2005. Here we assume that the forest structure changed very little during this period. Once a high quality BRDF model has been retrieved, the BRFs along the principal plane can be effectively modeled. In addition to the MODIS BRDF product, the MODIS Land Cover product (MCD12Q1, IGBP classes) (Friedl et al., 2002, 2010) was used to mask out nonforested lands.

\subsection{Field measurements}

During 2007, as part of the Echidna under-canopy LIDAR program, ground measured tree heights were acquired within two sites at both the Harvard and Howland Forests (Tian et al., in press). At Harvard Forest, a site consisting of young hardwood stands and another site of older hemlock stands were selected and are designated as Harvard hardwood and Harvard hemlock in Table 6. At Howland Forest, the two sites selected consisted of one with young spruce stands and another in a shelterwood location and they are designated as Howland tower and Howland shelterwood (Fig. 1). At most sites, five subplots with $20 \mathrm{~m}$ radius are used to characterize a $100 \mathrm{~m}$ by $100 \mathrm{~m}$ square (Tian et al., in press), although only 3 subplots were acquired at the Howland tower site because of time constraints. The tree heights were measured in the

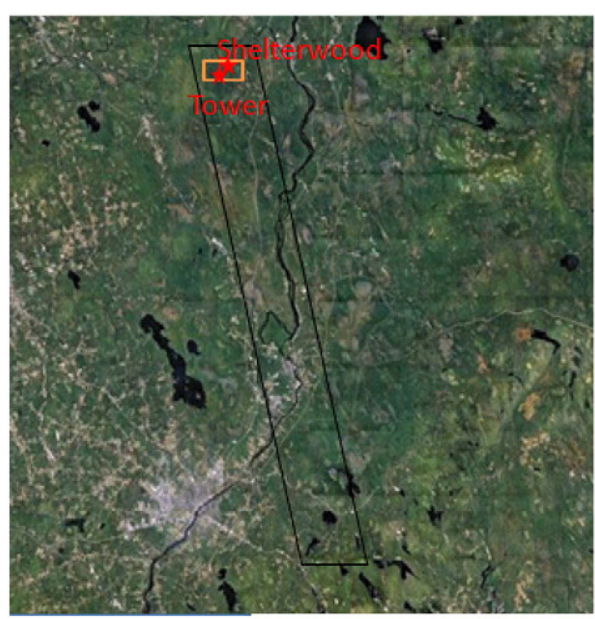

Howland Forest

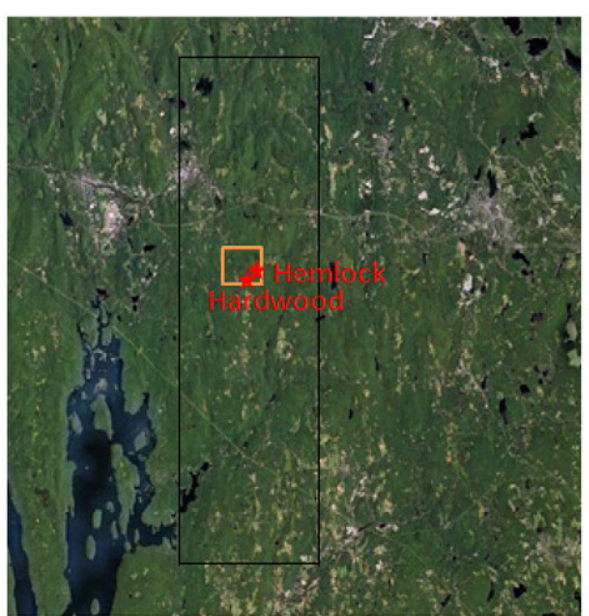

Harvard Forest

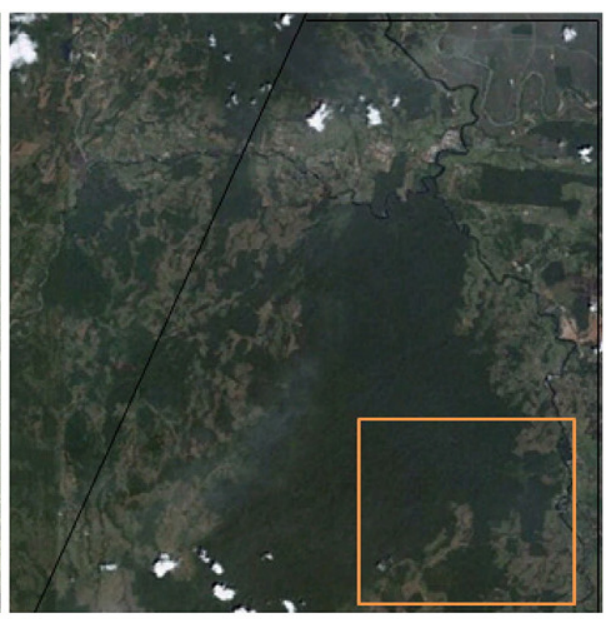

La Selva Forest

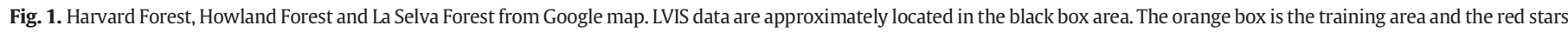
are the location of the field canopy heights measurements. 
Table 1

Basic information on Howland forest, Harvard forest and La Selva Forest at a $500 \mathrm{~m}$ spatial resolution from LVIS canopy height.

\begin{tabular}{|c|c|c|c|c|c|c|}
\hline Trial & \#pixels & $\begin{array}{l}\text { Mean height } \\
(\mathrm{m})\end{array}$ & $\begin{array}{l}\text { Min height } \\
(\mathrm{m})\end{array}$ & $\begin{array}{l}\text { Max height } \\
(\mathrm{m})\end{array}$ & Standard Deviation & $\begin{array}{l}\text { Median height } \\
(\mathrm{m})\end{array}$ \\
\hline Howland forest & 1112 & 15.59 & 7.05 & 25.25 & 3.60 & 15.76 \\
\hline Harvard forest & 866 & 21.34 & 9.23 & 25.89 & 2.60 & 21.85 \\
\hline La Selva Forest & 1279 & 20.55 & 5.08 & 39.81 & 9.52 & 19.81 \\
\hline
\end{tabular}

field with Laser range finders. Ten individual trees were measured at each subplot (one every $36^{\circ}$ azimuth). In order to make these field measurements comparable with the LVIS H100 canopy height, the subplot canopy height is calculated by the mean value of the top four trees in each subplot and then all the subplots heights within the site are averaged to get the site canopy height.

Field measured albedo is not available for the three study sites. A field needleleaf albedo was measured during the Flakaliden field campaign between June 25 and July 4, 2002 using an ASD hand-held spectroradiometer (Analytical Spectral Devices Inc., 1999) (Huang et al., 2007). Flakaliden, dominated by boreal forest, is located in northern Sweden.

\section{Methods}

The structure of a forest canopy determines the interaction probabilities for scattered photons moving through the canopy. These probabilities effectively represent the variability and "roughness" of the canopy, which might be expected to be locally related to height. Spectrally invariant probabilities have been successfully used to retrieve canopy vertical information from higher resolution directional observations (Schull et al., 2007).

\subsection{Spectrally invariant parameters}

The escape and recollision probabilities can be derived from measured data by relating atmospherically corrected BRFs to leaf albedo as (Schull et al., 2007),

$\frac{B R F_{\lambda}(\Omega)}{\omega_{\lambda}}=p B R F_{\lambda}(\Omega)+R_{1}(\Omega)$

where $R_{1}(\Omega)$ is loosely referred to as the escape probability in direction $\Omega ; p$ is the recollision probability, which describes the probability that a photon scattered by a phytoelement will recollide with another phytoelement. Note that the hemispherical integral of $R_{1}$ over the whole sphere is proportional to the total escape probability $(1-p)$ (Schull et al., 2011). The integration eliminates the sensitivity of $p$ to the viewing geometry. However the empirically derived recollision probability can exhibit a weak sensitivity to variation in the solar-viewing geometry which can be neglected in a range typically used in satellite remote sensing (Huang et al., 2007; Smolander \& Stenberg, 2005). Finally, $\omega_{\lambda}$ is the spectral single-scattering albedo for the medium.

In using this equation, we assume a vegetation canopy is bounded from below by a nonreflecting surface. In this analysis, we estimate $p$ and $R_{1}(\Omega)$ by fitting Eq. (1) to the MODIS multi-angle, multispectral data. In this way, we obtain escape and recollision probabilities for each 500-m grid cell at each of the forest sites.

\subsection{Linear regression models}

Given two types of parameters for each pixel-spectrally invariant probabilities and directional reflectances reconstructed from the BRDF model parameters-we tested each for its ability to predict canopy height as estimated using LVIS data. For the BRDF model parameters, we calculated the BRFs along the principal plane at the
View Zenith Angles (VZA) given in Table 2. Principal plane data were used because directional effects on reflectance are greatest along this axis. This provided a regression model as follows:

$$
\begin{aligned}
\left(\begin{array}{c}
H_{1} \\
H_{2} \\
\vdots \\
H_{m}
\end{array}\right)= & \left(\begin{array}{lllll}
1 & B R F_{11}\left(\Omega_{1}\right) \cdots B R F_{11}\left(\Omega_{n}\right) & B R F_{21}\left(\Omega_{1}\right) \cdots & B R F_{21}\left(\Omega_{n}\right) B R F_{31}\left(\Omega_{1}\right) \cdots B R F_{i 1}\left(\Omega_{n}\right) \\
1 & B R F_{12}\left(\Omega_{1}\right) \cdots B F_{12}\left(\Omega_{n}\right) & B R F_{22}\left(\Omega_{1}\right) \cdots & B R F_{22}\left(\Omega_{n}\right) \\
\vdots & \vdots & B R F_{32}\left(\Omega_{1}\right) \cdots B R F_{i 2}\left(\Omega_{n}\right) \\
1 & B R F_{1 m}\left(\Omega_{1}\right) \cdots B F_{1 m}\left(\Omega_{n}\right) & B R F_{2 m}\left(\Omega_{1}\right) \cdots & \vdots & B R F_{2 m}\left(\Omega_{n}\right) \\
B R F_{3 m}\left(\Omega_{1}\right) \cdots B R F_{i m}\left(\Omega_{n}\right)
\end{array}\right) \\
& \left(\begin{array}{c}
x_{0} \\
x_{11} \\
\vdots \\
x_{1 n} \\
x_{21} \\
\vdots \\
x_{2 n} \\
x_{31} \\
\vdots \\
x_{i n}
\end{array}\right)
\end{aligned}
$$

where $H_{m}$ is the LVIS-derived height of $m$ th pixel and $B R F_{i m}\left(\Omega_{n}\right)$ is the $n$th view angle BRF for band $i$; and $x_{n}$ are the fitted regression weights.

For the regression using the spectrally invariant parameters, the regression model was:

$$
\left(\begin{array}{l}
H_{1} \\
H_{2} \\
\vdots \\
H_{m}
\end{array}\right)=\left(\begin{array}{llll}
1 & R_{11}\left(\Omega_{1}\right) & \cdots & R_{11}\left(\Omega_{n}\right) \\
1 & R_{12}\left(\Omega_{1}\right) & \cdots & R_{12}\left(\Omega_{n}\right) \\
\vdots & \vdots & & \vdots \\
1 & R_{1 m}\left(\Omega_{1}\right) & \cdots & R_{1 m}\left(\Omega_{n}\right)
\end{array}\right) \cdot\left(\begin{array}{c}
x_{0} \\
x_{1} \\
\vdots \\
x_{n}
\end{array}\right)
$$

where $R_{1 m}\left(\Omega_{n}\right)$ is the escape probability at the $n$th view angle. We neglect the sensitivity of the recollision probability to view angle.

\subsection{Clumping effect}

Eq. (1) requires the single scattering albedo of the medium. Because a forest canopy will exhibit clumping at several scales, which will affect the escape and recollision probabilities, the single scattering albedo of the medium depends partly on the scale of the observations. The scale at which the single scattering albedo is defined can be a single leaf, clumping of leaves, a tree crown, or a satellite pixel. Single scattering albedos at different scales are linked by their recollision probability as follows (Ganguly et al., 2008; Smolander \& Stenberg, 2003):

$\omega_{1}=\omega_{0} \frac{1-p_{0,1}}{1-p_{0,1} \omega_{0}}$

where $p_{0,1}$ is the probability that a photon scattered by vegetation elements in one scale like a leaf or needle will hit another elements within the same clumping scale; $\omega_{0}$ is the one-scale (e.g. leaf) single

Table 2

View zenith angles used for the multiangle observations. Here $\mathrm{a}, \mathrm{f}$, and $\mathrm{n}$ stand for the afterward, forward, and nadir looking direction and A, B, C, and D represent different camera angles.

\begin{tabular}{llllllll}
\hline View direction & \multicolumn{2}{l}{ Aft-looking } & & \multicolumn{3}{l}{ Nadir-looking } & \multicolumn{3}{l}{ Forward-looking } \\
\hline Camera & Ca & Ba & Aa & An & Af & Bf & Cf \\
Angle (degree) & 60 & 45.6 & 26.1 & 0.0 & 26.1 & 45.6 & 60 \\
\hline
\end{tabular}


scattering albedo; and $\omega_{1}$ is the coarser clumping-scale (e.g. shoot) single scattering albedo. This formulation can be extended to successively coarser scale clumping, for example, clumping of leaves within plant crowns. When used in Eq. (1), the coarser albedo $\left(\omega_{1}\right)$ retrieves different values of escape ( $\left.R_{1 \text { new }}\right)$ and recollision probability $\left(p_{\text {new }}\right)$ that are appropriate to the coarser scale.

Combining the least squares regression solution to Eq. (3) with Eq. (4), we can derive:

$R_{\text {new }}=R_{1} /\left(1-p_{0,1}\right)$

$p_{\text {new }}=\left(p-p_{0,1}\right) /\left(1-p_{0,1}\right)$

which provides

$R_{1} /(1-p)=R_{1 \text { new }} /\left(1-p_{\text {new }}\right)$

This means that $R_{1}$ normalized by its integral over all directions does not depend on the choice of the albedo and, consequently, on the scale (Schull et al., 2011).

So if the relative proportions of the leaf biochemical constituents are the same between the intrinsic leaf scale albedo and the coarser scale albedo (Lewis \& Disney, 2007) the choice of different single scattering albedo is assumed to have little or no impact on the information content of the escape probability. This is borne out in Table 3 by comparing the correlations (described in detail below) between LVIS determined canopy heights and heights generated by escape probabilities with various single scatting albedos and modeled values at Howland Forest. Conifer leaf scale albedo for four bands closely related to the first four MODIS bands (Blue, Green, Red and NIR) was measured during the Flakaliden field campaign (Huang et al., 2007) while the coarser scale albedos were taken from the MODIS pixel of the MCD43A3 albedo product where the land cover has determined the pixel to be a pure cover type at Howland forest. The PROSPECT (Jacquemoud \& Baret, 1990) leaf optical model for estimating leaf-level reflectance and transmittance was also used to provide modeled leaf scale albedos. Needleleaf pine parameters (Nilson et al., 1999) were used to simulate leaf albedo for Howland Forest: with a chlorophyll content of $\mathrm{C}_{\mathrm{AB}}=51.4 \mathrm{mg} / \mathrm{cm}^{2}$, an effective water thickness of $\mathrm{C}_{\mathrm{w}}=0.0250 \mathrm{~cm}$, a protein content of $C_{p}=0.0001 \mathrm{~g} / \mathrm{cm}^{2}$, cellulose and lignin content of $\mathrm{C}_{\mathrm{c}}=0.0045 \mathrm{~g} / \mathrm{cm}^{2}$, and a leaf mesophyll structure of $\mathrm{N}=2.55$.

However, since tree species and foliage shape do have an impact on the derivation in Eq. (7), the relationship is also dependent on forest type. Rautiainen et al. (2009) showed the different relationships between LAI and the recollision probability at a large number of broadleaf and coniferous forests ground plots. Therefore, different scale escape probabilities do not remain proportional as in Eq. (7) for larger areas which contain many different forest types. As a result, a classification of the forest type is required before application of this spectrally invariant method.

\subsection{Canopy height estimation}

Schull et al. (2007) and Kimes et al. (2006) both found high correlations between AirMISR data averaged to a $283 \mathrm{~m}$ resolution and LVIS height at Howland Experimental Forest. To examine the ability of

\section{Table 3}

Correlation coefficients between escape probability estimated canopy heights and LVIS canopy heights using different scales of scattering albedos and 4 bands (Blue, Green, Red, and NIR) for Howland Forest.

\begin{tabular}{llll}
\hline $\begin{array}{l}\text { Different scale } \\
\text { albedo }\end{array}$ & $\begin{array}{l}\text { Measured leaf } \\
\text { albedo }\end{array}$ & $\begin{array}{l}\text { PROSPECT modeled } \\
\text { leaf albedo }\end{array}$ & $\begin{array}{l}\text { Coarser } \\
\text { albedo }\end{array}$ \\
\hline Correlation coefficients & 0.65 & 0.65 & 0.64 \\
\hline
\end{tabular}

spaceborne coarser resolution modeled MODIS data to predict canopy height, we repeated their analysis in two ways. First, we fitted the RTLSR BRDF model parameters to the MODIS data for this location, calculated BRFs at the same illumination and view zenith angles (Tables 2 and 3), and tested the ability of the modeled MODIS directional reflectances and escape probabilities to reproduce LVIS heights. To assess accuracy, we used a bootstrap procedure in which we randomly selected one-third of the pixels to develop each height regression model and then applied this to the remaining two-thirds of the pixels to predict their heights, reporting the correlation coefficient and standard error of correlation coefficients. The selection and regression process was repeated 200 times to reduce variance in the random selection of pixels. Secondly, we applied these analyses to larger extended regions at the Howland Experimental Forest, the Harvard Forest, and the La Selva Forest in Costa Rica. While a needleleaf albedo is relatively representative of the foliage at Howland Forest which is dominated by needleleaf trees, Harvard Forest is a mixture of broadleaf and needleleaf trees and La Selva Forest is a mixture of hundreds of plant species. Therefore it is difficult to find a representative measured leaf albedo that can stand for all of these species to estimate escape probability. However, coarser scale albedo values from MODIS can be used to represent a mixture of many species and therefore in these extended area efforts, we have used albedos from taken from MODIS pixels with a pure forest cover as a surrogate leaf albedo to generate escape probability.

\section{Results and discussion}

As canopy height predictions were made using escape probabilities, we found that the addition of spectral bands increased the correlations and the values of the standard error of correlation coefficients decreased (Table 4). As more samples stabilize the regression estimation, an increase in the number of bands was found to help decrease the noise and improve the accuracy of estimation of the escape probability. Therefore in Table 4, we show the testing of the estimation of the 2 spectral invariant parameters by using a range of 2 bands to 7 bands of MODIS data in the regressions. The correlation coefficients between escape probability estimated canopy heights and LVIS canopy heights were improved from 0.64 to 0.66 by using 3 bands instead of just 2 bands and to 0.69 by using 7 bands.

As discussed above, the potential for using MODIS data to extrapolate spectrally invariant parameters to height relationships over a larger area at Howland Forest was tested (Fig. 2). Here we used the MODIS land cover product to remove all non-forested pixels and we also excluded any MODIS BRDF/Albedo values that were flagged as low quality.

Table 4

Correlation coefficients between escape probability estimated canopy heights and LVIS canopy heights and the standard deviation of correlation coefficients generated by using different numbers of MODIS land bands (http://modis.gsfc.nasa.gov/about/ specifications.php) of the Howland forest. The coarser scale MODIS scattering albedos and 7 VZAs were utilized.

\begin{tabular}{|c|c|c|}
\hline Number of bands & $\begin{array}{l}\text { Correlation coefficient } \\
\text { between escape probability } \\
\text { estimated canopy heights } \\
\text { and LVIS canopy heights }\end{array}$ & $\begin{array}{l}\text { Standard deviation } \\
\text { of correlation } \\
\text { coefficients }\end{array}$ \\
\hline 2 bands (Band 1, Band 2) & 0.64 & 0.07 \\
\hline $\begin{array}{l}3 \text { bands (Band 1, Band 2, } \\
\text { Band 4) }\end{array}$ & 0.66 & 0.07 \\
\hline $\begin{array}{l}4 \text { bands (Band1, Band 2, Band 4, } \\
\text { Band 5) }\end{array}$ & 0.67 & 0.06 \\
\hline $\begin{array}{l}5 \text { bands (Band 1, Band 2, Band 4, } \\
\text { Band 5, Band } 6 \text { ) }\end{array}$ & 0.67 & 0.05 \\
\hline $\begin{array}{l}6 \text { bands (Band 1, Band 2, Band 4, } \\
\text { Band 5, Band 6, Band 7) }\end{array}$ & 0.68 & 0.05 \\
\hline $\begin{array}{l}7 \text { bands (Band 1, Band 2, Band 3, } \\
\text { Band 4, Band 5, Band 6, Band 7) }\end{array}$ & 0.69 & 0.05 \\
\hline
\end{tabular}




\section{Howland Forest}
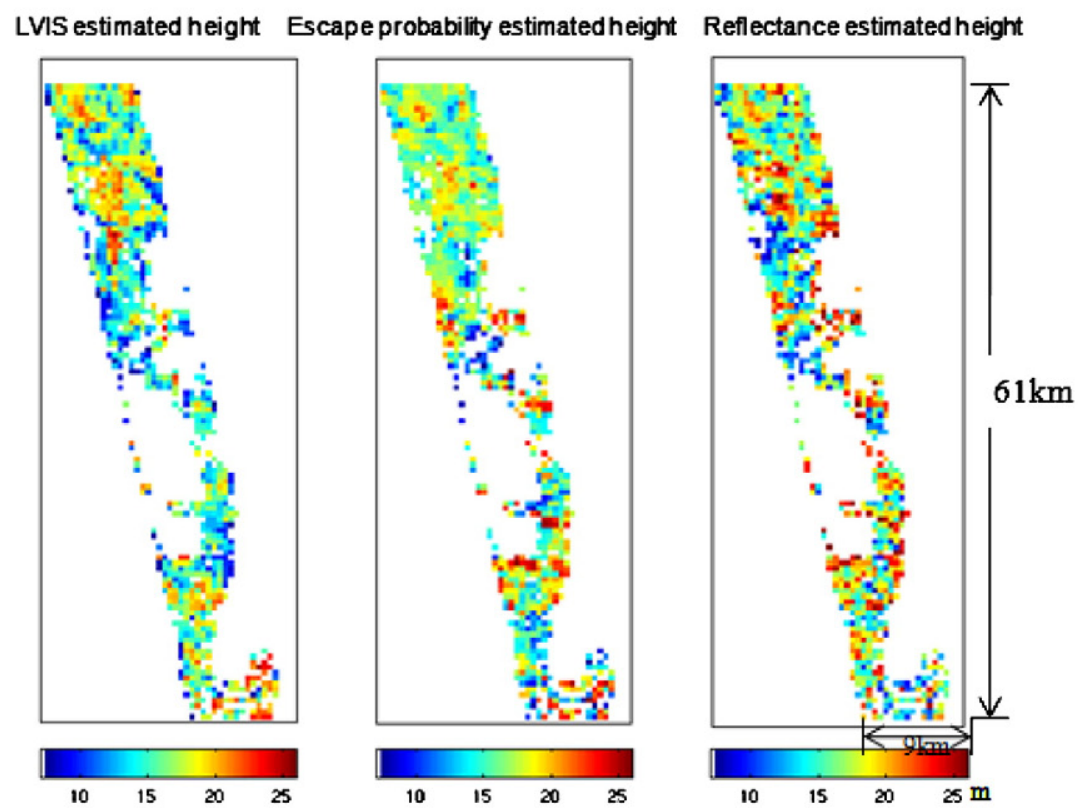

\section{Harvard Forest}

LVIS estimated height Escape probability estimated height Reflectance estimated height
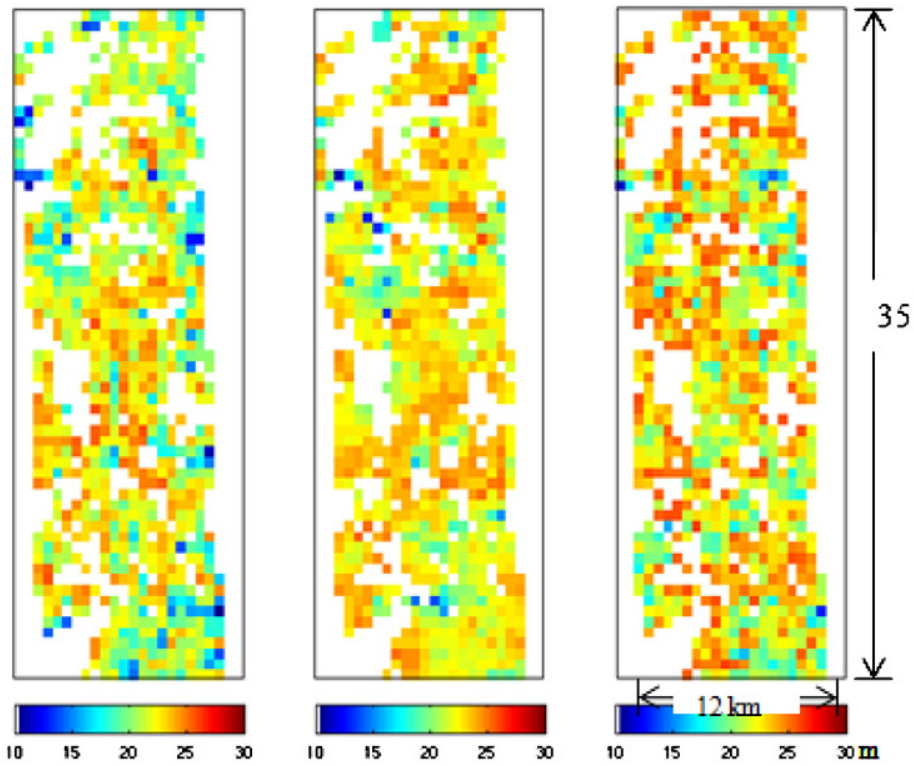

$35 \mathrm{~km}$

LVIS estimated height
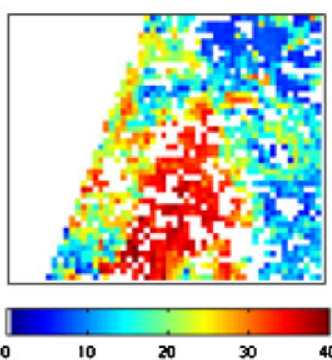

\section{La Selva Forest}

Escape probability estimated height
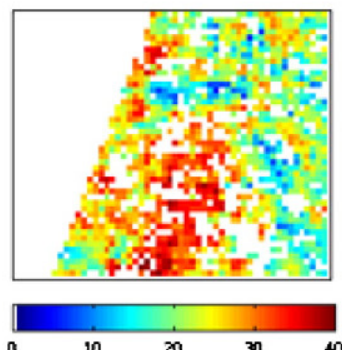

Reflectance estimated height

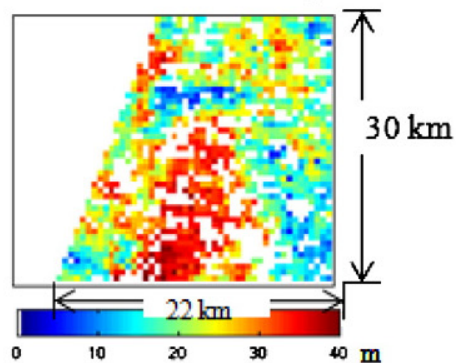

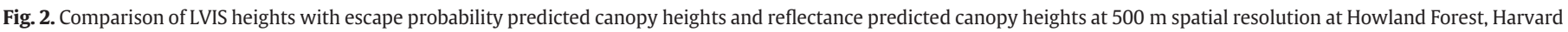
Forest and La Selva Forest. 
Table 5

Comparison of MODIS escape probability and MODIS reflectance estimated canopy heights and LVIS canopy heights at the extended sites at $500 \mathrm{~m}$ spatial resolution.

\begin{tabular}{|c|c|c|c|c|c|c|c|c|}
\hline \multirow[t]{2}{*}{ Trial } & \multicolumn{2}{|c|}{$\begin{array}{l}\text { Correlation coefficients with LVIS } \\
\text { canopy heights }\end{array}$} & \multicolumn{2}{|l|}{ RMSE, $\mathrm{m}$} & \multicolumn{2}{|l|}{ Bias, $\mathrm{m}$} & \multicolumn{2}{|c|}{ Probability that difference $<5 \mathrm{~m}$} \\
\hline & $\begin{array}{l}\text { Escape probability } \\
\text { estimated canopy } \\
\text { heights }\end{array}$ & $\begin{array}{l}\text { Reflectance } \\
\text { esitmated } \\
\text { canopy heights }\end{array}$ & $\begin{array}{l}\text { Escape probability } \\
\text { estimate canopy } \\
\text { heights }\end{array}$ & $\begin{array}{l}\text { Reflectance } \\
\text { estimated } \\
\text { canopy heights }\end{array}$ & $\begin{array}{l}\text { Escape probability } \\
\text { estimate canopy } \\
\text { heights }\end{array}$ & $\begin{array}{l}\text { Reflectance } \\
\text { estimated } \\
\text { canopy heights }\end{array}$ & $\begin{array}{l}\text { Escape probability } \\
\text { estimated canopy } \\
\text { heights }\end{array}$ & $\begin{array}{l}\text { Reflectance } \\
\text { estimated } \\
\text { canopy heights }\end{array}$ \\
\hline $\begin{array}{l}\text { Howland Forest, } \\
\quad 61 \times 9 \mathrm{~km}\end{array}$ & 0.66 & 0.63 & 2.53 & 2.96 & -0.20 & -0.42 & 0.83 & 0.79 \\
\hline $\begin{array}{l}\text { Harvard Forest, } \\
35 \times 12 \mathrm{~km}\end{array}$ & 0.55 & 0.54 & 2.63 & 2.82 & -0.44 & -0.57 & 0.91 & 0.87 \\
\hline $\begin{array}{l}\text { La Selva Forest, } \\
30 \times 22 \mathrm{~km}\end{array}$ & 0.78 & 0.82 & 3.83 & 3.67 & -0.32 & -0.03 & 0.69 & 0.77 \\
\hline
\end{tabular}

Therefore we estimated the canopy height over the entire $61 \times 9 \mathrm{~km}$ area that was covered with LVIS with a subset of $3 \times 5 \mathrm{~km}$ as training area using the 7 MODIS bands, 7 VZAs, and a $38^{\circ}$ solar zenith angle. The training area was selected from a Google map image which indicated that the area was covered by a pure forest. Most canopy heights at Howland were found to be in the range of $10 \mathrm{~m}$ to $25 \mathrm{~m}$. The correlation coefficient between escape probability estimated canopy heights and the LVIS canopy heights was 0.66 and was 0.63 when using the reflectance at $500 \mathrm{~m}$ spatial resolution. The escape probability performs better in terms of Root Mean Squared Error (RMSE) (2.53 vs $2.96 \mathrm{~m}$ ), biases ( $-0.20 \mathrm{vs}-0.42 \mathrm{~m}$ ) and the probability of correct retrievals: $83 \%$ of differences between the LVIS height and the escape probability estimated canopy height is less than $5 \mathrm{~m}$ (while only 79\% of the differences between the LVIS height and the reflectance estimated canopy height is less than $5 \mathrm{~m}$ (Table 5)).

In addition to Howland, a larger-area was also tested at Harvard Forest. The total area investigated was a region of about $35 \times 12 \mathrm{~km}$ which was covered with LVIS data. A subset of only $3.5 \times 3.5 \mathrm{~km}$ was used as the training area. Most canopy heights at Harvard are in the range of 15 to $25 \mathrm{~m}$. The correlation coefficient between escape probability estimated canopy heights and LVIS canopy heights is 0.55 and the relative RMSE and bias are $2.63 \mathrm{~m}$ and $-0.44 \mathrm{~m}$ (Table 5). As much as $91 \%$ of difference between the LVIS height and the escape probability estimated canopy height is less than $5 \mathrm{~m}$. Despite the lower correlation coefficient, the canopy heights estimated at Harvard using escape probability have greater probabilities of achieving an estimate within $5 \mathrm{~m}$ of the LVIS height than at Howland Forest. It must be noted that with the small height range at Harvard, these results are not particularly different than use of a mean height value of $20 \mathrm{~m}$. The accuracy depends on the canopy heights variation, forest density, the mixture of different species and so on. Further inspection however reveals that most pixels with large differences between the LVIS and estimated heights are actually mixed land types that have been labeled as forest, e.g. treed areas along rivers, lakes, residential areas etc. If these mixed pixels are more rigorously excluded, the correlation coefficients improve to 0.60 (escape probability) and 0.56 (reflectance).

The extrapolation results from the tropical La Selva Forest also show similar correlation coefficients, but here the reflectance-derived heights perform slightly better (Table 5 ). The total area covered by LVIS data is about $30 \times 22 \mathrm{~km}$ and a subset of $10 \times 10 \mathrm{~km}$ is used as the training area. Most canopy heights at La Selva are in a much greater range of 7 to $40 \mathrm{~m}$. The correlation coefficients between estimated canopy heights and LVIS heights are 0.78 and 0.82 using escape probability and reflectance respectively. The RMSE and bias are $3.83 \mathrm{~m}$ and $-0.32 \mathrm{~m}$ between escape probabilities estimated canopy heights and LVIS canopy heights. At La Selva, 69\% of the differences between the LVIS canopy heights and the escape probability estimated canopy height are less than $5 \mathrm{~m}$. Escape probabilities at this site may perform a little worse than reflectances directly because of dense tropical rain forest is comprised of a mixture of a large number of forest species. Both the escape probability and reflectance estimated canopy heights match well with LVIS canopy heights in the southern part of the region (Fig. 2), but there is a relatively larger discrepancy in the northeast part where the forest is very sparse.

Table 6 compares the field measured heights with the LVIS derived heights and the MODIS derived heights at Harvard Forest and Howland Forest. The bias between ground mean heights and the escaped probability estimated heights are $0.03 \mathrm{~m}, 0.59 \mathrm{~m}, 0.17 \mathrm{~m}$ and $2.49 \mathrm{~m}$ respectively. Note that only 3 subplots were acquired at the Howland tower site and this may contribute to the larger bias at this location as well as the probable bias inherent between the fine scale ground measurements (obtained in an area of $100 \mathrm{~m}$ by $100 \mathrm{~m}$ ) and the $500 \mathrm{~m}$ gridded spatial resolution of the MODIS data that occurs at all of the sites. Although there is a 4-year gap in time between MODIS derived height in 2003 and ground measurements in 2007, repeated field measurements at these same sites in 2009 show the growth of the forest is very slow and is less than $1 \mathrm{~m}$ from 2007 to 2009 .

There is an obvious advantage to using escape probabilities derived from MODIS multi-angle data reconstructed along the principal plane due to its frequent global coverage and the availability of seven spectral bands. However, the relatively coarse $500 \mathrm{~m}$ gridded spatial resolution of the MODIS BRDF/Albedo product must still be considered somewhat of a drawback. Note that the escape probability approach captures canopy height information with fewer variables than the approach which makes direct use of the reflectance bands. While regression formulas must be developed to relate the MODIS derived spectrally invariant variables to canopy height parameters for a particular forest type and region, such high quality canopy structure data may be available routinely in the future from the proposed Deformation, Ecosystem Structure and Dynamics of Ice (DESDynI) mission.

\section{Conclusions}

The potential for retrieving canopy heights was explored at Howland Forest, at Harvard Forest in the northeastern USA, and at the tropical La Selva Forest in Costa Rica. The results indicate that the correlation between the directional escape probability and LVIS canopy height is sensitive to the number of bands available and the correlation coefficients

Table 6

Comparison of ground measured canopy heights from $100 \mathrm{~m}$ by $100 \mathrm{~m}$ plots at Howland and Harvard Forests and the corresponding $500 \mathrm{~m}$ MODIS estimated forest canopy heights.

\begin{tabular}{|c|c|c|c|c|}
\hline Location & $\begin{array}{l}\text { Harvard } \\
\text { hardwood }\end{array}$ & $\begin{array}{l}\text { Harvard } \\
\text { hemlock }\end{array}$ & $\begin{array}{l}\text { Howland } \\
\text { shelterwood }\end{array}$ & $\begin{array}{l}\text { Howland } \\
\text { tower }\end{array}$ \\
\hline Number of subplots & 5 & 5 & 5 & 3 \\
\hline LVIS canopy height (m) & 24.89 & 24.02 & 16.96 & 18.38 \\
\hline Ground mean canopy height (m) & 22.96 & 23.24 & 18.31 & 17.61 \\
\hline $\begin{array}{l}\text { Escape probability estimated } \\
\text { canopy height }(\mathrm{m})\end{array}$ & 22.99 & 22.65 & 18.14 & 20.1 \\
\hline $\begin{array}{l}\text { Reflectance estimated canopy } \\
\text { height }(\mathrm{m})\end{array}$ & 23.25 & 22.83 & 16.21 & 19.05 \\
\hline
\end{tabular}


improve when additional wavebands are added. At Howland Forest, the correlation coefficients increase from 0.64 (two bands) to 0.69 (seven bands).

The correlation coefficients associated with the use of escape probabilities retrieved from 7 bands and 7 VZAs are 0.66, 0.55, and 0.78 for Howland Forest, Harvard Forest, and La Selva Forest respectively and the relative RMSEs are $2.53 \mathrm{~m}, 2.63 \mathrm{~m}$ and $3.83 \mathrm{~m}$ with results somewhat improved if only fully forested pixels were considered. In these cases, $69 \%$ to $91 \%$ of the differences between escape probability estimated canopy heights and LVIS canopy heights were less than $5 \mathrm{~m}$. The choice of different scales of single scattering albedo did not seem to impact the results within the same forest type.

DESDynI aims to provide periodic narrow swaths of high quality high resolution LIDAR data over the globe. Despite the moderate resolution of reflectances reconstructed from the MODIS BRDF/Albedo product, this limited study indicates a potential for multi-angle, multi-spectral reflectances to be used to extrapolate narrow swath LIDAR canopy structure information to larger regions. This technique needs to be tested on many more forests with varying tree heights, canopy densities, species mixtures, and phenologies. The requirement that the relationships only be developed within common forest species also needs to be explored further. However, this initial study illustrates a potential new use for readily available moderate resolution multi-angle multi-spectral data.

\section{Acknowledgements}

We would like to acknowledge the entire LVIS team for use of the LVIS data. This research was supported by NASA grants NNX08AE94A, NNG06GI92G, NNX09AI30G, NNX08AE81G, National Key Basic Research Development Program of China (2007CB714407) and National Natural Science Foundation of China (40871163).

\section{References}

Analytical Spectral Devices (ASD), Inc. (1999). ASD technical guide (4th ed.). Boulder CO, USA: ASD Inc.

Anderson, J., Martin, M. E., Smith, M. L., Dubayah, R. O., Hofton, M. A., Hyde, P., et al. (2006). The use of waveform lidar to measure northern temperate mixed conifer and deciduous forest structure in New Hampshire. Remote Sensing of Environment, $105,248-261$

Blair, J. B., Rabine, D. L., \& Hofton, M. A. (1999). The Laser Vegetation Imaging Sensor (LVIS): A medium-altitude, digitization-only, airborne laser altimeter for mapping vegetation and topography. ISPRS Journal of Photogrammetry and Remote Sensing, $54,115-122$.

Chopping, M., Moisen, G. G., Su, L., Laliberte, A., Rango, A., Martonchik, J. V., et al. (2008) Large area mapping of southwestern forest crown cover, canopy height, and biomass using the NASA Multiangle Imaging Spectro-Radiometer. Remote Sensing of Environment, 112, 2051-2063.

Chopping, M., Schaaf, C. B., Zhao, F., Wang, Z., Nolin, A. W., Moisen, G. G. et al. (in press) Forest structure and aboveground biomass in the southwestern United States from MODIS and MISR. Remote Sensing of Environment.

Friedl, M. A., Mclver, D. K., Hodges, J. C. F., Zhang, X., Muchoney, D., Strahler, A. H., et al. (2002). Global land cover mapping from MODIS: Algorithms and early results. Remote Sensing of Environment, 83, 287-302.

Friedl, M. A., Sulla-Menashe, D., Tan, B., Schneider, A., Ramankutty, N., Sibley, A., et al. (2010). MODIS Collection 5 global land cover: Algorithm refinements and characterization of new datasets. Remote Sensing of Environment, 114, 168-182.

Ganguly, S., Schull, M. A., Samanta, A., Shabanov, N. V., Milesi, C., Nemani, R. R., et al. (2008). Generating vegetation leaf area index earth system data record from multiple sensors. Part 1: Theory. Remote Sensing of Environment, 112, 4333-4343.

Heiskanen, J. (2006). Tree cover and height estimation in the Fennoscandian tundrataiga transition zone using multiangular MISR data. Remote Sensing of Environment, $103,97-114$
Huang, D., Knyazikhin, Y., Dickinson, R. E., Rautiainen, M., Stenberg, P., Disney, M., et al. (2007). Canopy spectral invariants for remote sensing and model applications. Remote Sensing of Environment, 106, 106-122.

Jacquemoud, S., \& Baret, F. (1990). PROSPECT: A model of leaf optical properties spectra. Remote Sensing of Environment, 34, 75-91.

Jenkins, J. C., Chojnacky, D. C., Heath, L. S., \& Birdsey, R. A. (2004). Comprehensive database of diameter-based biomass regressions for North American tree species. Gen. Tech. Rep. NE-319. Newtown Square, PA: U.S. Department of Agriculture, Forest Service, Northeastern Research Station 45 pp.

Kimes, D. S., Ranson, K. J., Sun, G., \& Blair, J. B. (2006). Predicting lidar measured forest vertical structure from multi-angle spectral data. Remote Sensing of Environment, $100,503-511$.

Knyazikhin, Y., Martonchik, J. V., Myneni, R. B., Diner, D. J., \& Running, S. W. (1998). Synergistic algorithm for estimating vegetation canopy leaf area index and fraction of absorbed photosynthetically active radiation from MODIS and MISR data. Journal of Geophysical Research, 103(D24), 32257-32275.

Knyazikhin, Y., Schull, M. A., Xu, L., Myneni, R. B., \& Samanta, A. (2011). Canopy spectral invariants. Part 1: A new concept in remote sensing of vegetation. Journal of Quantitative Spectroscopy and Radiative Transfer, 112, 727-735.

Lewis, P., \& Disney, M. (2007). Spectral invariants and scattering across multiple scales from within-leaf to canopy. Remote Sensing of Environment, 109, 196-206.

Lucht, W., Schaaf, C. B., \& Strahler, A. H. (2000). An algorithm for the retrieval of albedo from space using semiempirical BRDF models. IEEE Transactions on Geoscience and Remote Sensing, 38, 977-998.

Martonchik, J. V., Diner, D. J., Pinty, B., Verstraete, M. M., Myneni, R. B., Knyazikhin, Y., et al. (1998). Determination of land and ocean reflective, radiative and biophysical properties using multiangle imaging. IEEE Transactions on Geoscience and Remote Sensing, 36, 1266-1281.

Mõttus, M. (2007). Photon recollision probability in discrete crown canopies. Remote Sensing of Environment, 110, 176-185.

Mõttus, M., \& Stenberg, P. (2008). A simple parameterization of canopy reflectance using photon recollision probability. Remote Sensing of Environment, 112, 1545-1551.

Mõttus, M., Stenberg, P., \& Rautiainen, M. (2007). Photon recollision probability in heterogeneous forest canopies: Compatibility with a hybrid GO model. Journal of Geophysical Research, 112, D03104. doi:10.1029/2006JD007445

Nilson, T., Kuusk, A., \& Leroy, M. (1999). A comparison of forest BDRF simulated by the forest reflectance model and determined by airborne POLDER for some BOREAS sites. Proceedings of ALPS99 Symposium, January 18-22, Méribel, 2, 1-4.

Patenaude, G., Hill, R. A., Milne, R., Gaveau, D. L. A., Briggs, B. B. J., \& Dawson, T. P. (2004). Quantifying forest above ground carbon content using LiDAR remote sensing. Remote Sensing of Environment, 93, 368-380.

Rautiainen, M., Mõttus, M., \& Stenberg, P. (2009). On the relationship of canopy LAI and photon recollision probability in boreal forests. Remote Sensing of Environment, 113, $458-461$.

Rautiainen, M., \& Stenberg, P. (2005). Application of photon recollision probability in coniferous canopy reflectance simulations. Remote Sensing of Environment, 96, 98-107.

Schaaf, C. B., Gao, F., Strahler, A. H., Lucht, W., Li, X., Tsang, T., et al. (2002). First operational BRDF, albedo nadir reflectance products from MODIS. Remote Sensing of Environment, 83, 135-148.

Schull, M. A., Ganguly, S., Samanta, A., Huang, D., Shabanov, N. V., Jenkins, J. P., et al. (2007). Physical interpretation of the correlation between multi-angle spectral data and canopy height.Geophysical Research Letters, 34. doi:10.1029/2007GL031143 (L18405).

Schull, M. A., Knyazikhin, Y., Xu, L., Samanta, A., Carmona, P. L., Lepine, L., et al. (2011). Canopy spectral invariants: A theoretical basis for classification forest types from hyperspectral data. Journal of Quantitative Spectroscopy and Radiative Transfer, 112, $736-750$.

Smolander, S., \& Stenberg, P. (2003). A method to account for shoot scale clumping in coniferous canopy reflectance models. Remote Sensing of Environment, 88, 363-373.

Smolander, S., \& Stenberg, P. (2005). Simple parameterizations of the radiation budget of uniform broadleaved and coniferous canopies. Remote Sensing of Environment. $94,355-363$.

Stenberg, P. (2007). Simple analytical formula for calculating average photon recollision probability in vegetation canopies. Remote Sensing of Environment, 109, 221-224.

Tian, Y., Yang, X., Zhao, F., Wang, Z., Zhang, Q., Jupp, D., et al. (in press). Measuring of forest structure and biomass in New England Forest stands using Echidna ${ }^{\circledR}$ groundbased Lidar. Remote Sensing of Environment.

Tritton, L. M., \& Hornbeck, J. W. (1982). Biomass equations for major tree species of the Northeast. General Technical Report NE-6: USDA Forest Service, Northeastern Forest Experiment Station.

WWW1 (). Laser vegetation imaging sensor (LVIS), NASA Goddard space flight center. https://lvis.gsfc.nasa.gov 